\title{
Teaching NeuroImages: Raccoon eye in subarachnoid hemorrhage
}

Marlien Aalbers, MD, PhD, and J. Marc C. van Dijk, MD, PhD

Neurology ${ }^{\circledR}$ 2019;92:e1534-e1535. doi:10.1212/WNL.0000000000007180
Correspondence

Dr. Aalbers

mwaalbers@gmail.com

Figure Raccoon eye in subarachnoid hemorrhage from right ophthalmic artery aneurysm
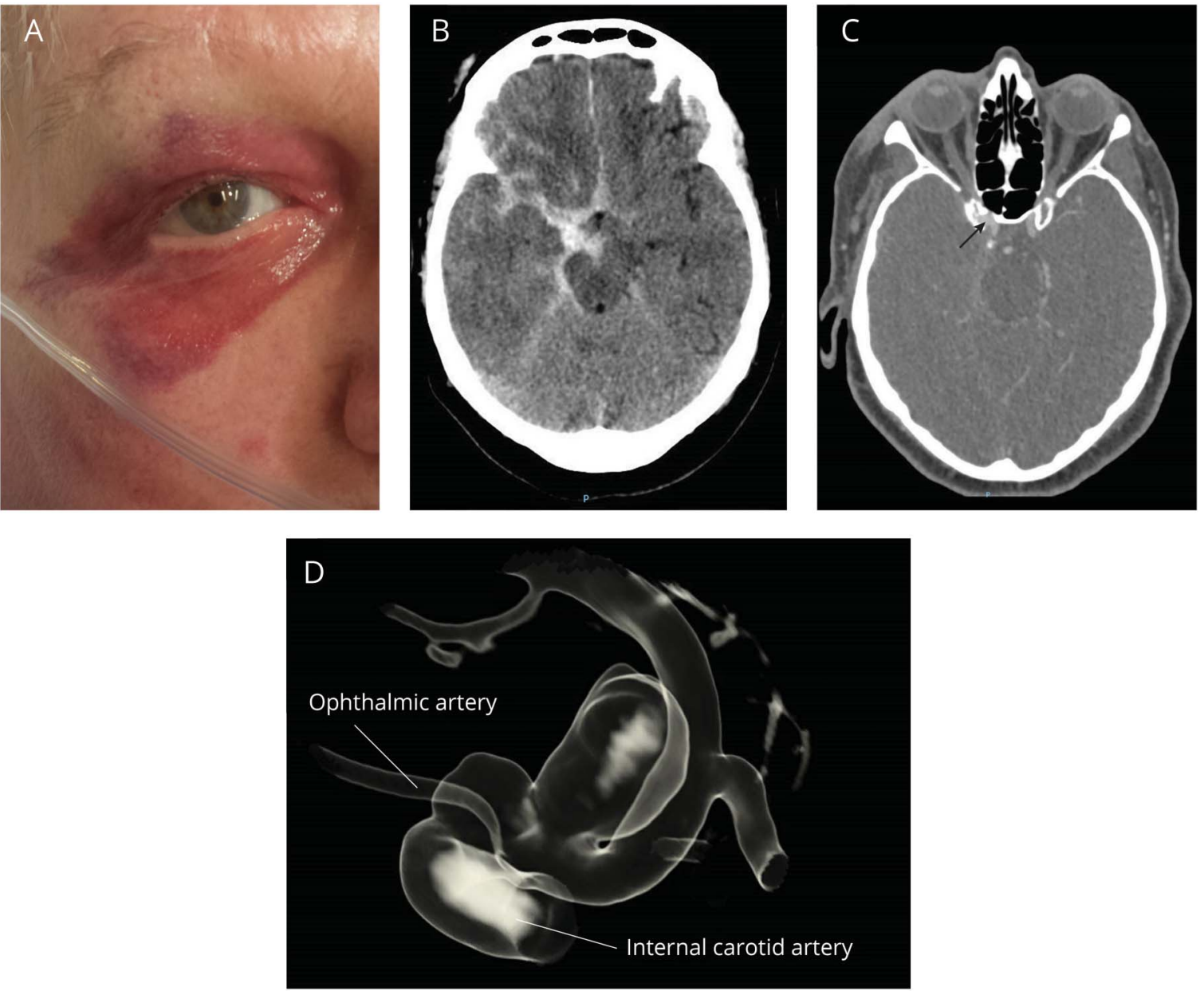

(A)Raccoon eye or periorbital ecchymosis. (B) CT demonstrates subarachnoid hemorrhage. Bilobar right ophthalmic artery aneurysm on (C) CT angiography and (D) angiogram. As it is partially located in the cavernous sinus, the immediate increased venous pressure in the cavernous sinus and (peri)orbital veins caused the ecchymosis.

A 73-year-old woman with a history of hypertension and diabetes presented with sudden headache and right-sided periorbital ecchymosis (figure). There was no history of trauma. Neurologic examination was unremarkable. Ophthalmologic examination revealed normal vision and intact ocular movements and no papilledema or retinal hemorrhage. CT angiography showed subarachnoid hemorrhage (SAH) from a right ophthalmic artery aneurysm (figure). The patient underwent successful endovascular treatment and made a full recovery. In addition
MORE ONLINE

\section{$\rightarrow$ Teaching slides}

links.lww.com/WNL/

A844 
to skull fracture and cavernous sinus thrombosis, SAH is an important differential diagnosis of sudden severe headache with periorbital ecchymosis.

Appendix Authors

\begin{tabular}{llll}
\hline Name & Location & Role & Contribution \\
\hline $\begin{array}{l}\text { Marlien W. } \\
\begin{array}{l}\text { Aalbers, MD, } \\
\text { PhD }\end{array}\end{array}$ & $\begin{array}{l}\text { University of } \\
\text { Groningen, the } \\
\text { Netherlands }\end{array}$ & Author & $\begin{array}{l}\text { Conceptualized } \\
\text { manuscript and } \\
\text { figure }\end{array}$ \\
\hline $\begin{array}{l}\text { J. Marc C. van } \\
\text { Dijk, MD, PhD }\end{array}$ & $\begin{array}{l}\text { University of } \\
\text { Groningen, the } \\
\text { Netherlands }\end{array}$ & Author & Revised manuscript \\
& & \\
\hline
\end{tabular}

\section{Study funding}

No targeted funding reported.

\section{Disclosure}

The authors report no disclosures relevant to the manuscript. Go to Neurology.org/ $\mathrm{N}$ for full disclosures. 


\section{Neurology}

\section{Teaching NeuroImages: Raccoon eye in subarachnoid hemorrhage Marlien Aalbers and J. Marc C. van Dijk \\ Neurology 2019;92;e1534-e1535 \\ DOI 10.1212/WNL.0000000000007180}

This information is current as of March 25, 2019

\section{Updated Information \& Services}

Subspecialty Collections

Permissions \& Licensing

Reprints including high resolution figures, can be found at: http://n.neurology.org/content/92/13/e1534.full

This article, along with others on similar topics, appears in the following collection(s):

\section{Clinical neurology examination}

http://n.neurology.org/cgi/collection/clinical_neurology_examination Eyelids

http://n.neurology.org/cgi/collection/eyelids

Subarachnoid hemorrhage

http://n.neurology.org/cgi/collection/subarachnoid_hemorrhage

Information about reproducing this article in parts (figures,tables) or in its entirety can be found online at:

http://www.neurology.org/about/about_the_journal\#permissions

Information about ordering reprints can be found online:

http://n.neurology.org/subscribers/advertise

Neurology ${ }^{\circledR}$ is the official journal of the American Academy of Neurology. Published continuously since 1951, it is now a weekly with 48 issues per year. Copyright () 2019 American Academy of Neurology. All rights reserved. Print ISSN: 0028-3878. Online ISSN: 1526-632X.

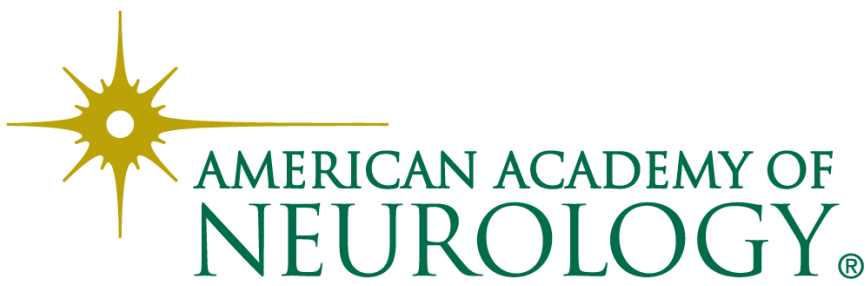

